\title{
Træk af idrætshistoriens historiografi
}

\author{
af Niels Kayser Nielsen
}

\section{1}

Der er noget befriende ved idræt: den er ikke entydig! Den kan være noget af det mest medrivende og noget af det mest indelukkede, det mest frastødende og mest fascinerende, mest eventyrlige og mest rationelle, mest undertrykkende og mest frigørende, man kan tænke sig. Og meget ofte er den alt dette på én og samme tid. I sit væsen er den gennemsyret af så megen dynamisk afspænding, så meget samspil på individuel basis, så megen modepræget tidløshed og så permanent revolutionering, at de skråsikre opfattelser må komme til kort. I det hele taget synes der ved idræt at være så megen mangetydighed på færde, at det snævre syn ikke slår til. Der er altså noget befriende ved idræt: den duer ikke til dogmatik!

Gælder dette for idrætten, er det ikke mindre karakteristisk for forskningen i idræt, at den er præget af mangfoldige holdninger, komplexe og vidtspændende teorier, differentierede metoder. Min hensigt med denne lille oversigt over idrætshistorieforskningens historie er da også at vise, at den hidtidige idrætsforskning har været præget af både paradoxer, dobbelttydighed og vild uenighed - ligesom man også fremover må ønske sig, at idrætsforskningens hus bliver en stor og rummelig bygning med plads til mange meninger.

Kaster vi et blik på enkelte af disse paradoxer, er det for det første bemærkelsesværdigt, at nogle af de vægtigste analyser af idrættens væsen og funktion findes i værker, som i grunden ,,intet har med fodbold at gøre“. Dvs. de pågældende værker bruger idrætten som illustration af og eksempel på en hovedtanke vedr. livet og døden, gruppen og individet etc. Vel sagtens fordi idrætten forekommer så gennemsigtig og velkendt, at den virker velegnet hertil. Man ved nok, at idrætten er så kolossalt betydningsudtrykkende, men anser den ikke for at være særligt betydnings-fuld i sig selv. Som eksempler på sådanne værker kunne nævnes Per Olov Enquists roman „Sekonden“ (1971), et af Jean-Paul Sartres filosofiske hovedværker „Critique de la raison dialectique“" (ty. udg. 1967), Tage Skou-Hansens „,Medløberen“ (1973), Hans-Jørgen Nielsens „Fodboldenglen“ (1979) og Siegfried Lenz: „Brot und Spiele“ (1959).

En variant af dette paradox består $i$, at alle taler om idræt, men ingen tager 
den for alvor alvorligt. I grunden ved man (herunder også de allerfleste faghistorikere) godt, at den ikke er så vigtig som inflation, husbyggeri, gode karakterer og kærlighed - og det til trods for at idrætten de sidste 100 år har været et massefænomen af betragtelige dimensioner, og til trods for at idrætten måske ligger tættere på den umiddelbare sansning, som er forudsætning for enhver forståelse og erkendelse. Eller i det mindste: på trods af en solid vesterlandsk tradition for en ligevægtende dualisme mellem krop og sjæl, ånd og legeme regnes idrætten forstået som kropsudfoldelse normalt for noget sekundært i forhold til hjernegymnastik.

Disse to paradoxer er så $i$ sin tur måske årsag til et tredje påfaldende paradox, nemlig at synet på idræt ikke følger de normale politiske og videnskabsmæssige skillelinjer. Her duer den forstenede opfattelse af venstre og højre ikke. Fra såvel borgerlig som socialistisk hold er man indbyrdes uenige, idet både folk der går ind for en borgerlig samfundsordning og marxister har indbyrdes vidt forskellige opfattelser af, hvad idræt er for noget, og af hvad den skal bruges til: er idræt et mål i sig selv eller er den først og fremmest middel til opnåelse af et andet mål?

Det fælles for disse tre paradoxer er så til gengæld ganske tydeligt: problemet er til stadighed dette, om idrætten skal analyseres, tolkes og vurderes på egne præmisser - som et selvstændigt interessefelt og forskningsfelt - eller om den må ses $i$ lyset af andet end sig selv som et mangefacetteret led i en historisk-samfundsmæssig totalitet, hvor den følgelig kun kan behandles på baggrund af forhold, som ligger uden for den selv?

\section{2}

Og vender vi os så til idrætshistoriens historiografi har opfattelsen heraf da også vekslet kraftigt, idet den ældste skriven idrætshistorie (1700- og 1800-tallets) først og fremmest focuserede på idrætten som sådan, løsrevet fra den samfundsmæssige sammenhæng idrætten indgik $\mathbf{i}$ - medens idrætsforskningen i dette århundrede i højere grad har båret præg af forsøg på at indskrive idrættens historie $i$ samfundets generelle historie, eller, mere historieløst, at indskrive idrætten en plads i samfundet, uden historiske perspektiver. Således at idrættens historie fra at have været et felt fortrinsvis for (idræts)historikere i højere grad er blevet et samfundsvidenskabeligt og socialvidenskabeligt, herunder også psykosocialt, forskningsområde.

Denne udvikling kan ikke overraske på baggrund af den udvikling, der har fundet sted inden for historieskrivningen generelt. Her har tendensen som helhed været bevægelsen fra en diakront til en synkront orienteret forskning $i$ historien, fra en fortællende begivenhedsdomineret historieskrivning med 
vægt på ,,hvad der egentlig skete " inden for politik og organisationer - til en i højere grad teoriorienteret og strukturelt præget opfattelse af, hvad der er historie.

Idrætshistorieskrivningen synes altså at følge den generelle bevægelsesretning for historieskrivning. Så meget mere må det så overraske, at idrætshistorien endnu ikke er blevet opfattet som et fuldgyldigt medlem af historiefamilien, på linje med andre historiske områder såsom arbejderbevægelseshistorie, familiehistorie, landbohistorie, idéhistorie etc. med selvstændig og respektabel status.

Men måske er der håb forude, for $i$ tråd med det seneste tiårs signaler inden for historieskrivningen i retning af en tilbagevenden til empirien og „,historierne i historien" kan man også inden for idrætshistorien iagttage en tilbagevenden til en forpligtelse på udforskning af idrætten som sådan, forstået som interesse for en først og fremmest kropslig aktivitet - i social og kulturel variation i tid og rum. Dette sker ofte ud fra den betragtning, at inden man indskriver idrættens historie i samfundets historie, må man vide, hvorledes idrættens historie som sådan egentlig var; og det er næppe ganske forkert at opfatte stiftelsen af „Dansk Idrætshistorisk Forening. Krop og kultur" som det hidtil mest synlige udtryk herhjemme for en sådan forpligtelse. Ikke at man forkaster de human- og socialvidenskabelige forskningsresultater, metoder og teoridannelser, og som det fremgår nedenfor af den selektive omtale heraf, er der meget at hente inspiration i på dette felt, men en solid viden om kropskulturen, idrættens tilrettelæggelse af kroppen set i et kultur- og socialvidenskabeligt lys, synes på ny at være rykket $i$ forgrunden - med de muligheder for en egl. fastlæggelse og kvalificering af forskningsfeltet, dette indebærer.

Videnskabshistorisk kan man da, måske lidt flot, tale om en dialektisk ophævelse i en højere enhed af de to omtalte forskningstilgange, således at samfundsvidenskabelig sportskritik og positiverende idrætshistoriske ,,fortællinger" ikke længere forstås som absolutte modsætninger, men som led i en samlet civilisationsperspektiverende forskning $i$ historisk lys.

Givet er det i det mindste, at man i dag, midt i 1980'erne, på baggrund af adskillige idrætshyldester og lige så megen kritik af sporten, skulle stå bedre rustet til en mere differentieret og udogmatisk idrætshistorisk forskning end på noget tidligere tidspunkt $\mathrm{i}$ dette århundrede - men lige så givet er det (jvf. nedenfor), at skal der skrives idrætshistorie i Danmark, skal det være nu, for så vidt som det empiriske kildegrundlag er truet på flere leder og kanter.

Efter dette vue kan vi så gå mere konkret til værks og se på den hidtidige idrætshistorieskrivning, hvor jeg disponerer ud fra treklangen: idrætshistorie som sådan - idrætshistorie præget af udblik til den generelle historie idræts(historie)forskning i sociologisk, psykologisk, idéhistorisk, antropologisk regi - med udblik til en ny, 4. fase: kropskulturhistorie. 
Blandt de værker af snæver idrætshistorisk art, som vor tids forskning kan trække på, må nævnes de encyklopædiske oversigtsværker over idrættens historie, som er blevet skrevet i bl.a. Tyskland og England fra forrige århundrede og $\mathrm{i}$ første halvdel af dette, med enkelte udløbere helt op til i dag. De bærer i reglen et umiskendeligt gammeldags historieskrivningspræg med endeløse redegørelser for idrættens udviklingshistorie år for år, af typen ,,så skete der det, og så skete der det, og ...", vægtning af person- og organisationsstof på bekostning af f.eks. idrættens kulturhistoriske og økonomiske baggrund, fortælling fremfor analyse, centrering omkring enkeltaspekter inden for idrætten i sig selv, såsom olympiadeforestillinger.

Det gælder således i større og mindre grad for værker som Francis Peabody Magoun jr: "History of Football from the Beginnings to 1871", Albrecht Wettwer: „Englischer Sport im 14. Jahrhundert“ (1933) samt to hjemlige værker, J. Weinberg: „Dansk Idræts Litteratur gennem tre Aarhundreder" (1916) og Fr. Knudsens ",Træk af Boldspillets historie“ (1933). På trods af de åbenlyse mangler og skævheder har denne forskningstradition imidlertid vist sig at være uhyre nyttig, og de senere årtiers mere nuancerede og socialhistorisk orienterede idrætshistorieskrivning har i høj grad kunnet hente stof til overvejelse og direkte anvendelse hos de gamle.

Tilsvarende gælder det for et nyere værk af samme skuffe, Carl Diems „Weltgeschichte des Sports und der Leibeserziehung“ (1960), at skønt belastet af ovenstående mangler (dansk idræt synes således næsten at være et spørgsmål om N.F.S. Grundtvig, Nachtegall og Niels Bukh) er værket så mættet med facts, at det er uomgængeligt for enhver idrætshistoriker, ligesom det med sin globalt anlagte karakter nok skal blive værdsat, når en mere komparativ idrætshistorie engang dukker op.

En guldgrube af empiriske data udgør ligeledes de jubilæums- og årsskrifter, skåret over den læst, der hedder ,år for år-historie“, som de store idrætsorganisationer og -foreninger har udsendt. Omend også de er belemrede med den traditionelle idrætshistoriske personfiksering rummer disse værker et væld af informationer om mesterskaber, klubgrundlæggelser, arrangementsformer, baneindvielser etc. samt undertiden stof om socialhistoriske og økonomiske forudsætninger.

Den samme centrering om den "store" historie i idrætten, dvs. forbundenes og organisationernes tilrettelæggende arbejde og de store mænds betydning, finder man derimod ikke $i$ et af de nyeste af disse mammutværker, nemlig Horst Ueberhorst (red.): „Geschichte der Leibesübungen“ (1980), som først og fremmest adskiller sig fra forgængerne ved at operere med meget vide rammer for, hvad der er idræt, og for hvorledes den skal analyseres. 
Behovet for en sådan udvidelse tilgodeses også i en lang række korrektiver, af mere begrænset omgang og mere afgrænset karakter, til den ,,altmodische" tradition. Vi kan ikke omtale blot en hundrededel af disse arbejder, men må i stedet pege på nogle overordnede retninger, hvor det fælles træk for disse er, at idrætshistorie ikke længere er et spørgsmål om begivenhedshistorie inden for idrætten i sig selv, men hvor idrætten sættes i relation til andre dele af historien og andre dele af samfundet.

\section{4}

Ser vi nu først på den forskningsinteresse, som prøver at skrive idrætshistorie $\mathrm{i}$ relation til den generelle historie, aftegner der sig groft set en 4-5 retninger.

Blandt de tydeligste alternativer til begivenheds-idrætshistorien finder vi den østeuropæiske idrætshistorieskrivning. Eksempelvis kan nævnes polakken Andrzej Wohls ,Die gesellschaftlich-historischen Grundlagen des bürgerlichen Sports“ (1973). Dette værk er, som titlen angiver, et specialværk i forhold til Diem og Ueberhorst, men det supplerer på glimrende vis, idet idrætten her er indsat i en materialistisk (marxistisk) ramme, som desuden $i$ udpræget grad tilgodeser de socialfilosofiske perspektiver og analyserer idrætten i forhold til socio-kulturelle strukturer. Værket har endvidere den fordel $\mathrm{i}$ forhold til så megen senere og samtidig marxistisk idrætsforskning, at det ikke forstår den nutidige idræts form og indhold som værende et resultat af blot kapitalistiske, industrialistiske forhold. - Ligeledes kan nævnes den særdeles omfattende østtyske idrætsforskning, med hovedsæde i Leipzig, hvor undersøgelser af idrættens rolle i revolutionsperspektiv (henholdsvis borgerskabets og arbejderklassens revolutioner) og idrættens kulturskabende potentialer $i$ fortid og nutid ofte har stået $i$ centrum for idrætshistorieskrivningen.

Inden for de vestlige alternativer til den traditionelle idrætshistorie påkalder især den vesttyske marxistiske strukturhistorieskrivning sig opmærksomhed, anført af forskere som Karin Rittner, Henning Eichberg og Chr. Graf von Krockow. Førstnævnte har bl.a. i ,,Sport und Arbeitsteilung. Zur sozialen Funktion und Bedeutung des Sports" (1976) grundigt og overbevisende redegjort for idrættens rødder tilbage $\mathrm{i}$ den middelalderlige udvikling af borgerpligtrationelle lag med tilhørende arbejdsdeling og abstraktionsudvikling. Samme forskningsinteresse ligger til grund for Henning Eichbergs bog „Leistung, Spannung, Geschwindigkeit im gesellschaftlichen Wandel des 18. und 19. Jahrhunderts" (1978) med dens idé- og socialhistoriske analyse af c-g-s systemets (længde, vægt og tid) historiske baggrund $\mathrm{i}$ industrialisering 
og homo faber-mentalitet. Men udover at have beskæftiget sig med idrætten set $i$ forhold til civilisatorisk udvikling af abstraktionsevner og kulturaliserede livsformer har $\mathrm{H}$. Eichberg udvidet den idrætshistoriske forskning til at omfatte så utraditionelle emner som antropologiske undersøgelser af f.eks. kropskultur på Sumatra og kultursociologiske analyser af bilsport i Vesteuropa (Centring 3-4/1982). Som en tredje repræsentant for den omfattende vesttyske forskning $\mathrm{i}$ relationen mellem idræt og industrialisering, med opkomsten af sport som resultat, kan nævnes Chr. Graf von Krockows ,,Sport und Industriegesellschaft" (1972), medens Wilhelm Hopfs mange arbejder fra de seneste ti år, hvor idrætten set som folkekultur er blevet fint belyst, både $\mathrm{i}$ henseende til udøvelse og overværelse/fascination, især bærer et socialhistorisk præg. Det samme gælder R. Lindner og H. Th. Breuers „,Sind doch nicht alles Beckenbauers" (om fodbold i Ruhrområdet), som repræsentant for adskillige eksempler på idrætshistorie ,,fra neden“, skrevet ud fra ,grav, hvor du står"-princippet.

En forsker som flere gange har figureret i W. Hopfs antologier er Norbert Elias, og med ham er samtidig knyttet forbindelsen til en tredje retning inden for moderne idrætshistorie, nemlig den enge/ske socialhistoriske idrætsforskning. Blandt de utallige værker kan her nævnes P. Mclntosh: „,Sport in Society" (1963), James Walwin: ",The Peoples Game“ (1975), Eric Dunning (red.): ,Football Hooliganism“ (1978), for så vidt som disse værker viser det for England så karakteristiske, at idræt analyseres ikke kun som de aktives idræts historie, men også ud fra et tilskuer- og brugersynspunkt (i bred forstand). Her anskues idrætten som folkekulturel institution $i$ forhold til hverdagsliv, ,local communities“ og traditionsbestand som led i en kulturel klassekamp, styret ikke så meget af partier, organisationer og bevægelser som af aktørerne selv på græsrodsniveau. Resultatet af denne forskning er bl.a. blevet en rigt facetteret sportssociologi, som andre lande (endnu) savner - med Eric Dunning og Norbert Elias som de store nestorer - samt en omfattende forskning i fænomenet ,,hooliganism “.

I skæringsfeltet mellem tysk og engelsk idrætshistorieskrivning befinder sig den skandinaviske, og skal man tale om et særkende for den nordiske idrætshistorie må det være beskæftigelsen med idrætshistoriske bevæge/ser.

Men desuden har, næppe overraskende, den hidtidige danske forskning især været påvirket af den tyske idrætshistorie og den tyske sportskritik. Af moderne arbejder gælder det således Hans Lyngby Jepsens „Idrættens forræderi“ (1973) og Gunnar Rasmussens ,Sportsjournalistik" (1974), som begge er influerede af den tyske ideologikritik af sporten og har dannet skole for megen sportskepsis i Danmark op igennem 1970'erne.

Tilsvarende er den svenske idrætshistorie i højere grad engelsk orienteret. 
Den opdyrkning af feltet idrættens historiske sociologi, som er så karakteristisk engelsk, genfindes f.eks. i Göran Patrikssons lille fine bog ,Idrottens historia i sociologisk belysning“ (1973) og til dels i Olle Halldéns ,Idrotten i det svenska samhället" (1971).

M.h.t. forskningen i idrætsbevægelser og idrættens historie i forhold til andre folkelige bevægelser har skandinavisk idrætsforskning leveret flere gode bidrag den seneste halve snes år, specielt hvad angår problemet idræt og den organiserede arbejderbevægelse. Nævnes kan således to artikler i Den jyske Historiker 19-20: „,Sportshistorie“ om henholdsvis arbejderidrætten og firmaidrætsbevægelsen, ligesom samme nr. indeholder en artikel om gymnastik-og skyttebevægelsen 1884-1905.

Størst opmærksomhed samler sig naturligt nok om Ove Korsgaards banebrydende værk „Kampen om kroppen. Dansk idræts historie gennem 200 år", som er den første større redegørelse for emnet på dansk. Karakteristisk nok ses også her idrætten i lyset af de „,folkelige“ bevægelser, det gælder især den grundtvigske gymnastikbevægelse og vor tids folkelige motionsbølger.

Vedr. den mindre fashionable del af dansk idræt, nemlig fodbold som folkeforlystelse, henvises til Anders W. Berthelsens sjove ,Frispark - om den danske fodboldbevægelses historie“" (1983), medens Bidrag 13-14 (1981): „,Sport og fascination“ i en række artikler skrevet af tidl. og nuværende aktive idrætsfolk beskæftiger sig med idrætten som socialisationsagentur, herunder også i forhold til kvindebevægelse og mandsroller.

For svensk vedkommende må nævnes to fremragende arbejder om idræt som politisk og social bevægelse, nemlig Jan Lindroths ,Idrottens väg till folkrörelse (1974), hvor idrætten ses ikke kun i lyset af arbejderbevægelsen, men også i forhold til et socio-kulturelt fænomen som afholdsbevægelsen, ligesom der gøres grundigt rede for bevægelser inden for idrætsbevægelsen, såsom den særegne svenske IFK-idræt - medens Rolf Pålbrandt i et metodisk og empirisk bundsolidt arbejde ,Arbetarrörelsen och idrotten 1919-1939“ (1977) har skrevet historiens pendant til Per Olov Enquists ,,Sekonden“. Som alternativ til disse to værker om den ,,pæne“ arbejderidræt må omtales en ofte overset artikel, nemlig Richard Estreen: „Spektakel, sport och politik“, i Häften för kritiska studier 2/1974, om den plebejiske folkekultur på de billige langsider.

Norsk idrætshistorisk forskning synes i højere grad end den danske og svenske at være båret af lokalhistoriske undersøgelser, hvilket næppe kan overraske i betragtning af den stærke tradition for lokalhistorie-videnskab i Norge - og det må klart siges, at der her er noget at lære af nordmændene (jvf. nedenfor).

Skal der rejses kritik af disse retninger inden for moderne europæisk 
idrætshistorie, må det gælde dens ofte manglende evne til at indfange de psyko-sociale og mentale dispositioner, som ligger til grund for og er en effekt af idrætsudøvelse og -overværelse. Indtil nu glimrer f.eks. den franske Annales-skoles begreber om kollektiv mentalitet og socialt „,klima“" næsten alle steder ved sit fravær i denne del af idrætshistorieskrivningen, ligesom den tyske Hannoverskoles socialisationshistoriske betragtninger heller ikke (endnu) synes indarbejdet i væsentligt omfang.

\section{5}

I mangel heraf er der til gengæld hjælp at hente inden for den del af idrættens historieskrivning, der horisontalt-synkront har beskæftiget sig med idrættens historie ikke i længdesnit, men i tværsnit: idrættens relation til det omgivende samfund og dets individer. Skal man også på dette felt pege på nogle overordnede grupperinger, drejer det sig om den især tyske og amerikanske sports-psykologi, repræsenteret af bl.a. Arnold Beissers beskæftigen sig med idrættens funktion som ,healer" " af anomiske splittelsestilstande, R.B. Aldermanns lidt (for) blinde tillid til idrætten som skaber af jeg-stærke, handlekraftige og tolerante individer, Otto Neumanns undersøgelser af sportens betydning for den psykiske habitus og identitetsdannelse. Fælles for denne forskning, i modsætning til den ovenfor, er forestillingen om sporten som en ,formålsfri“, legepræget foreteelse, der har udviklet sig naturvokset, og som netop fungerer bedst, når den er renset for krav om at skulle fungere, $i$ betydningen være formålstjenlig ( $i$ en bestemt sags tjeneste). At denne sportsforskning også står i opposition til den idrætshistorieskrivning, der har interesseret sig for sportens politiske relationer, nævnes kun for en ordens skyld.

Langt mere forfinet diskuterende og nuanceret i sit grundsyn er den psykologiske forskning i relationen idræt-aggression, som repræsenteret af bl.a. vesttyskeren Rolf Denker opfatter idrætten som en samfundsmæssig integrationsmekanisme: enhver form for idræt $i$ det moderne samfund er også en form for aggression, forårsaget af samfundsmæssigt skabt angst, men vel at mærke en fredelig, civiliseret aggression - det er bedre at være højdespringer end rocker.

Denne interesse for idræt som social regulator og integrationsformidler har naturligvis også kendetegnet meget af forskningen i idrætssociologi, hvor man også her må pege på amerikanske og tyske grupperinger omkring folk som John W. Loy for USA's vedkommende, Günther Lüschen, Hans Linde og Hans Lenk fra tysk side. Skønt ofte præget af den traditionelle sociologi-svaghed: ,vi ved ikke om det vi siger er væsentligt, men det er i det 
mindste sandt" og af selvfølgeligheder såsom ,flere unge end ældre dyrker sport", er det dog til denne forskning man skal gå, hvis man vil have noget at vide om social stratifikation i sporten, sporten som ",small group system", idrætsrekruttering etc., hvor denne positivistisk-empiriske videnskabsretning ofte har været $i$ stand til at levere et nødvendigt memento til mere spekulative teoridannelser, f.eks. som dementi af den velkendte myte om, at idræt først og fremmest har været og er en arbejderbeskæftigelse: idrætssociologien peger $i$ stedet på mellemlagene. - Og er man interesseret $i$ brasiliansk fodbold er det også her man skal henvende sig, idet et medlem af den amerikanske idrætssociologis yngre generation, Janet Lever, har skrevet en spændende bog, ,,Soccer Madness“ (1983) herom. Det er skam ikke lige kedeligt altsammen!

Medens disse to retninger som oftest har haft en grundliggende tillidsfuld holdning til idrætten, gør det modsatte sig som regel gældende for den tredje store retning inden for den psyko-socialt orienterede samfundsvidenskabelige idrætshistorie. Her tænkes på den humanistiske kulturkritik, hvor især de forskellige generationer af Frankfurterskolen har spillet en stor rolle med deres teorier (inspireret af Weber, Freud og Marx) om idræt som social lynafleder, kompensatorisk adfærd, sublimeret sexualenergi, pseudoophævelse af fremmedgørelse, træning $i$ autoritetslydighed, fordummende massekultur, fordobling af arbejdslivets tvang, og dermed en raffineret tilvænning til et liv som kapitalistisk lønarbejder, under foregivelse af frihed i fritiden. Hovedsigtet har her, uanset om vi har med 1., 2. eller 3. generation af Frankfurterskolen at gøre, været kampen for menneskelig myndighed og værdighed, som den moderne massesport opfattes som en forhindring af. Typiske eks. på denne idrætsforskning er bl.a. Jörg Richter (red.): „Die vertrimmte Nation oder Sport in rechter Gesellschaft" (1972) og Bero Rigauers opsamlingsværk fra 1979 med den lidt misvisende titel „Warenstrukturelle Bedingungen leistungssportlichen Handelns " - men også liberale teologer og humanistiske kultursociologer såsom Helmuth Thielecke og Alexander Mitscherlich har her leveret tankevækkende bidrag til idrætshistorien, se f.eks. Helmuth Plessner m.fl. (red.): „Sport und Leibeserziehung“ (1967).

Omend ofte præget af en aristokratisk forfaldsideologi, endimensional kriticisme og mangel på forståelse af kapitalismens dobbelthed af frihedsskabende undertrykkelse er denne humankritiske idrætsforskning umulig at komme udenom for idrætshistorikeren i dag. Dens insisteren på frisk luft og lys over land har været sund oven på megen lummer bragesnak om ,en sund sjæl $i$ et sundt legeme" - på trods af at man ofte glemte at afsløre myten om det ,,sunde legeme“", men nok så meget drog den ,,sunde sjæl“ i tvivl.

Videnskabsinternt har denne sportskritik da også banet vejen for den 
foreløbig 4. og sidste fase af idrættens historieskrivning, som på mange leder er en slags syntese af de ovenfor nævnte retninger og positioner, nemlig den civilisationskritiske forskning $i$ idrættens kulturhistorie.

Skal man pege på påfaldende træk ved dette tilsyneladende nye ryk inden for den humanistiske idrætsforskning, må det blive følgende:

- en vældig udvidelse af idrætsbegrebet til at omfatte også aktiviteter som jagt, bilsport, dans, yoga, body building etc.

- en tilbagevenden til de historiske længdesnit, dels i tid i form af interesse for bl.a. vikingetidens idrætter, dels $\mathrm{i}$ rum $\mathrm{i}$ form af antropologisk og etnologisk inspirerede undersøgelser af fremmede kulturers kropskultur.

- en eliminering af problemstillingen: er sporten undertrykkende eller frigørende, til fordel for bl.a. socialisationshistoriske analyser af idræt som værende på én gang knægtelse og befrielse.

- en interesse ikke kun for den (u)sunde sjæl, men også den (u)sunde krop.

- en generelt uhildet og fantasifuld tilgang til idrætshistorie i almindelighed og kropskultur i særdeleshed.

Skal der til slut sættes navne og titler på dette sidste skud på idrætshistoriens stamme, må det blive den franske Foucault-inspirerede kropsforskning, repræsenteret af bl.a. Georges Vigarello: "Le corps redressé" (1978), men også i videre kropsteoretisk forstand postmodernister som Jean Baudrillard og Paul Virilio - samt den vesttyske Norbert Elias-inspirerede kropshistoriske forskning med Dietmar Kamper og Volker Rittner som de to mest kendte. Se f.eks. deres ,Zur Geschichte des Körpers“" (1976) og D. Kamper og Ch. Wolf (red.): ,Die Wiederkehr des Körpers“" (1982).

Af andre mere specialiserede værker kan nævnes Rudolf zur Lippes „Naturbeherrschung am Menschen I-II" (1974) om den civilisatoriske dobbelthed af sanseapparatets forfinelse og kroppens instrumentalisering $\mathrm{i}$ henholdsvis den norditalienske renaissance og den franske enevældes hofverden, Wolfgang Schivelbuschs ,,Geschicte der Eisenbahnreise“ (1977), om jernbanens (maskinverdenens) betydning for ændringen af oplevelsen af tid og rum i 1800-tallet samt Stephan Oettermanns ,Zeichen auf der Haut" (1979), om tatoveringens historie i Europa. Her er kropskultur for alle pengene!

Herhjemme udgør især tidsskriftet Centring, hjemmehørende på Gerlev Idrætshøjskole, et forum for denne nyeste forskning, hvor man gennem de seneste par år har bragt adskillige oversættelser af og introduktioner til den kontinentale forskning med Eigil Jespersen som en kyndig oversætter - samt rapporter fra seminarer 0.l. Og her må vi så stoppe og foretage en opsamling. 
Som det forhåbentlig skulle være fremgået af det ovenstående, aftegner der sig inden for idrætshistoriens historiografi i meget grove træk en 3-faset udvikling, der med navnet på den svenske forløber for Idrætshistorisk Forening passende kunne betegnes som en ,idrætshistorie - samfund"udvikling, for så vidt som tendensen synes at have været en bevægelse fra forskning $\mathrm{i}$ idrætshistorie som sådan, over en forskning $\mathrm{i}$ idrættens historie $\mathrm{i}$ forhold til den generelle historie i lange linjesnit, og frem til en idrætshistorie skrevet $\mathrm{i}$ lyset af samfundet $\mathrm{i}$ tværsnit, under inddragelse af nabodiscipliner som sociologi, psykologi, idéhistorie, socialantropologi m.v. Medens vi så $i$ dag aner konturerne af en 4. idrætshistorisk fase, en bredt anlagt civilisationshistorisk undersøgelse af makkerparret krop og kulturhistorie. - Der er altså nok at tage fat i.

Men samtidig må det nok ud fra en idrætshistorisk synsvinkel pointeres, at skal de djærve projekter, de vidtløftige teorier og de raffinerede metoder blive til noget, fordres der bestandige kompletteringer $i$ form af empirimættende undersøgelser af idrætten i lokalhistorisk frøperspektiv. De ,store" ideer om den ,store" idrætshistorie har det som kæden: ikke stærkere end det svageste led. - Omvendt er denne lokalhistoriske idrætsforskning ikke meget bevendt, hvis den blot består i en ukritisk lobhudling af fortidens store bedrifter på sogneplan, udført år for år af fremragende mænd og kvinder i selvopofrende danskhed. Også den ,lille“ idrætshistorie må kunne tåle kritikkens og problematiseringens klare lys.

Her synes der at være tale om et stort set uopdyrket felt, hvor indtil nu kun ganske lidt arbejde er udført. Eksempelvis kan nævnes Aksel Astrup: „En gymnastikforening og dens betydning for et sogns ungdom", i Hardsyssel Årbog 1982. Men hvor mange små idrætsforeningers protokoller og regnskabsbøger ligger endnu ikke uudforskede hen?

Hvor mange gamle idrætsudøvere og foreningsaktive venter endnu ikke på at blive interviewet? Hvor mange erindringer er endnu ikke læste? Som eks. på sådanne erindringer om idræt og friluftsliv omkr. år 1900 og tilbage $\mathrm{i}$ 1800-tallet, se Steffen Steffensen: „Bag lave længer" (1967) og Anton Nielsen: ,Landsbyliv i trediverne“ (1894). - Antallet er legio, og tiden er inde. Om få år lever disse ældste idrætsfolk ikke mere, og protokollerne m.v. er så måske også borte.

Under mit arbejde med idrættens historie $\mathrm{i}$ et sydjysk landsogn i perioden 1920-1950 er jeg på sidste side i ,Protokol for Herslev Gymnastik- og Ringriderforening 1938-1953“" stødt på følgende kloge ord: „,Opbevar denne Protokol. Der kan være Notater, som kan have senere Interesse!" Ja, mon ikke - og ikke blot skal den opbevares; den skal også bruges. Idrættens historie skal ikke på museum, den skal frem i dagens lys. 


\section{Skenhedskonkurrencen igaar.}

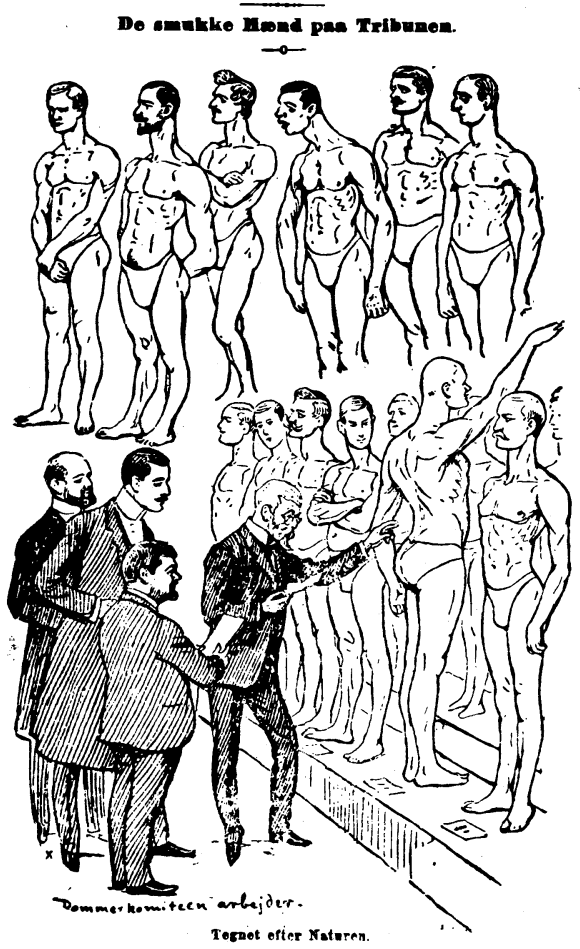

Skønhedskonkurrence for mænd. Fra århundredskiftet og frem til 1. verdenskrig arrangerede Dansk Atlet Union hvert år skønhedskonkurrence for mænd. Tegningen, der stammer fra 1905 (Pol. 18.9.) må siges at tage en vis ironisk distance til begivenheden. Det fremgår i øvrigt også af artiklen, der fastslår at ,Det nøgne mandlige Legeme skal være af ualmindelig harmonisk bygning for at tage sig ud i rolig oprejst Stilling: dets virkelige Skønhed kommer som regel først til sin Ret under Bevægelse“. Fem år efter (11.7. 1910) har Politiken ikke ændret holdning: „Hele konkurrencen har et ret uæstetisk Præg, man mindes Dyrskuerne og venter blot, at Afkommet ogsaa skal præsenteres for at Bedømmelsen kan blive fuldt ud retfærdig. “ Dommer i konkurrencerne var to læger og to billedhuggere.

Berlingske Tidende finder $i 1905$ heller ikke disse ,offentlige Sessioner ganske smagfulde“, men synes de har en stor opdragende betydning. „Oprindelig troede „de stærke mænd“, at de var de smukkeste, men Dommerne har efterhånden fået påvist, at det er de lette Idrætsmænd ..., der er Skønhedsidealet nærmest". 